Article

\title{
Impacts of Climate Change on Mean Annual Water Balance for Watersheds in Michigan, USA
}

\section{Yinqin Zhang ${ }^{1}$, Bernard Engel ${ }^{2, *}$, Laurent Ahiablame ${ }^{3}$ and Junmin Liu ${ }^{4}$}

1 College of Water Conservancy and Hydropower, Hebei University of Engineering, 178 S. Zhonghua Street, Handan 056000, Hebei, China; E-Mail: yinqin928@163.com

2 Department of Agricultural and Biological Engineering, Purdue University, 225 S. University Street, West Lafayette, IN 47907, USA

3 Department of Agricultural and Biosystems Engineering, South Dakota State University, Brookings, SD 57007, USA; E-Mail: Laurent.Ahiablame@sdstate.edu

4 College of Water Resources and Architectural Engineering, Northwest A \& F University, 23 Weihui Road, Yangling 712100, Shanxi, China; E-Mail: jml@nwsuaf.edu.cn

* Author to whom correspondence should be addressed; E-Mail: engelb@purdue.edu; Tel.: +1-765-494-1162; Fax: +1-765-496-1115.

Academic Editor: Miklas Scholz

Received: 16 April 2015 / Accepted: 29 June 2015 / Published: 7 July 2015

\begin{abstract}
Evaluation of water balance at the watershed scale is a fundamental step for estimating streamflow in watersheds. Mean annual water balance of 17 watersheds across Michigan were evaluated by comparing observed streamflow with simulated streamflow estimated using Fu's Equation, which is based on the Budyko Hypothesis. The Budyko Hypothesis describes mean annual water balance as a function of available water and energy. Impact of long-term climatic controls (e.g., precipitation, potential evapotranspiration $(\mathrm{ET} P))$ on mean annual water balance was also investigated with Fu's Equation. Results indicated that observed streamflow ranged from 237 to $529 \mathrm{~mm}$ per year, with an average of $363 \mathrm{~mm}$ per year in the study watersheds during 1967-2011. On average, 40\% of long-term precipitation in the study watersheds was converted into surface runoff. The performance of Fu's Equation in estimating mean annual streamflow resulted in Root Mean Square Error (RMSE) value of $64.1 \mathrm{~mm} /$ year. Mean annual streamflow was sensitive to changes in mean annual precipitation, and less sensitive to changes in mean annual $\mathrm{ET}_{\mathrm{p}}$ in the watersheds. With the increase of baseflow index (BFI), mean annual streamflow was less sensitive to climate change. Overall, different contributions of baseflow to
\end{abstract}


streamflow modified the impact of climate controls on mean annual water balance in the baseflow-dominated watersheds.

Keywords: water balance; baseflow; climate sensitivity; Budyko Hypothesis; Michigan

\section{Introduction}

Water balance refers to the quantitative description of the hydrologic cycle. It is often expressed with water balance equations (i.e., the relationship between input and output of water through an area during a given time period). A water balance model is generally selected based on specific project requirements, available data, and the application scope of the model. Empirical data of catchment all over the world indicate that the long-term water balance is primarily controlled by water supply (i.e., precipitation) and energy demand (i.e., potential evapotranspiration), these relatively simple models have been developed [1-4]. The Budyko Hypothesis, the relationship between actual evapotranspiration ratio (i.e., the ratio of actual evapotranspiration to precipitation) and climate aridity index (i.e., the ratio of potential evapotranspiration to precipitation), is a useful tool to examine watershed water balance and to investigate the effects of climate change and watershed characteristics on the hydrologic cycle [5-9].

Although a variety of equations satisfying the Budyko Hypothesis can be found in previous studies [4,10-15], Budyko-type equations with optimizable parameters are particularly useful for modeling mean annual and annual water balance in individual watersheds [16,17]. Fu's Equation, an analytical solution of the Budyko Hypothesis, is a one-parameter conceptual model derived from dimensional analysis and mathematical reasoning (rather than a simple empirical fit to hydrologic data) [12]. Fu's Equation can provide reasonable results for estimating mean annual and annual water balances in most individual watersheds $[15,18]$. Based on its simplicity, Fu's Equation was utilized in this study to evaluate long-term water balance at catchment scales.

Long-term water balance is affected by climatic controls (i.e., precipitation (P) and potential evapotranspiration $\left.\left(\mathrm{ET}_{\mathrm{p}}\right)\right)$ according to the Budyko Hypothesis. The Budyko water balance approach for estimating the climatic sensitivity has been widely applied in previous studies [8,19-22]. However, studies relating groundwater (e.g., baseflow) to Budyko Hypothesis were relatively rare. Wang et al. [23] explored the effects of soil texture and groundwater (e.g., baseflow) on mean annual and annual water balances of watersheds in the Nebraska Sand Hills, based on the Budyko Hypothesis. Results suggested that soil texture may greatly modify the influence of climate on regional water balance; and a water storage term needed to be included in the Budyko Hypothesis on annual time scales when baseflow contribution was significant.

This study is a continuous work based on [24], in which 17 watersheds have been used to develop regression equations for estimating baseflow and baseflow index. On average, baseflow accounted for $70 \%$ of the total streamflow in those 17 watersheds [24]. The specific objective of this study were to (1) test the applicability of Fu's Equation in estimating mean annual water balances for 17 watersheds in Michigan; and (2) investigate the relationship between baseflow and climatic sensitivity in Michigan watersheds using Fu's Equation. The evaluation of watershed water balance in this study was intended 
to provide quantitative insight into water balance response to climatic factors in various watersheds, especially in baseflow-dominated watersheds.

\section{Materials and Methods}

\subsection{Data Used}

Watershed characteristics and meteorological variables used for water balance calculations in this study include: Watershed location (latitude of the gaging stations), annual precipitation (P), annual streamflow (Q), maximum daily temperature (averaged over all days in the month) ( $\mathrm{T}_{\max }$ ) and minimum daily temperature (averaged over all days in the month) ( $\left.T_{\mathrm{min}}\right)$, and solar radiation $\left(\mathrm{R}_{\mathrm{a}}\right.$ ). Annual precipitation and monthly average maximum and minimum daily temperature for the study watersheds were derived from Parameter-elevation Regressions on Independent Slopes Model (PRISM) climate analysis system [25]. All datasets mentioned above were compiled using ArcGIS 10 [26] for a period of 1967 to 2011. Streamflow data were obtained from USGS (United States Geological Survey) gaging stations [27]. The Eckhardt filter method [28] in Web-based Hydrograph Analysis Tool program was used to partition daily streamflow records into direct runoff and baseflow for the study period of 1967 to 2011 [29]. The default recess constant and $\mathrm{BFI}_{\max }$ values of 0.98 and 0.8 were employed, respectively. The specific principle of the recursive partitioning algorithm was shown in detail in the study by Zhang et al. [24]. Then, baseflow index (BFI) was calculated by dividing mean annual baseflow by mean annual streamflow to quantify groundwater contributions to streamflow in the 17 study watersheds.

\subsection{Potential Evapotranspiration Calculation}

The Hargreaves method [30] is based on time series of average maximum and minimum temperature data and solar radiation. It has been widely used to estimate ETP in previous studies [31-33]. The equation can be expressed as [30]:

$$
\mathrm{ET}_{\mathrm{p}}=0.0023 \mathrm{R}_{\mathrm{a}}\left(\frac{\mathrm{T}_{\text {max }}+\mathrm{T}_{\min }}{2}+17.8\right) \sqrt{\left(\mathrm{T}_{\text {max }}-\mathrm{T}_{\text {min }}\right)}
$$

where $\mathrm{ET}_{\mathrm{p}}$ is the potential evapotranspiration, $\mathrm{mm} / \mathrm{d} ; \mathrm{T}_{\max }$ and $\mathrm{T}_{\min }$ are the maximum monthly temperature and minimum monthly temperature, respectively, ${ }^{\circ} \mathrm{C} ; \mathrm{R}_{\mathrm{a}}$ is the extraterrestrial solar radiation, $\mathrm{mm} / \mathrm{d}$.

Daily solar radiation of individual gaging stations was calculated based on the latitude values (shown in Table 1) using the calculator of extraterrestrial solar radiation tool [34].Monthly time series of average maximum and minimum temperature data along with the computed solar radiation were used to calculate monthly $\mathrm{ET}_{\mathrm{p}}$ in $\mathrm{mm} / \mathrm{d}$ using Equation (1). Annual $\mathrm{ET}_{\mathrm{p}}$ in the study watersheds was derived from summing monthly $\mathrm{ET}_{\mathrm{p}}$ of each year. 
Table 1. Gaging stations and water balance components of seventeen watersheds in Michigan.

\begin{tabular}{|c|c|c|c|c|c|c|c|c|c|c|c|}
\hline Gaging Station ID & Station Name and Location & Latitude & Delineated Area $\left(\mathbf{k m}^{2}\right)$ & $\mathbf{P}(\mathbf{m m} / \mathbf{y r})$ & $\operatorname{ET}_{\mathbf{P}}(\mathbf{m m} / \mathbf{y r})$ & $\mathbf{Q}(\mathbf{m m} / \mathbf{y r})$ & $\mathbf{E T}_{\mathbf{a}}(\mathbf{m m} / \mathbf{y r})$ & $\frac{E T_{P}}{P}$ & $\mathbf{Q} / \mathbf{P}$ & $\frac{E T_{a}}{P}$ & BFI \\
\hline 04040500 & Sturgeon River near Sidnaw & 46.584 & 429.8 & 878 & 832 & 416 & 462 & 0.95 & 0.47 & 0.53 & 0.66 \\
\hline 04043050 & Trap Rock River near Lake Linden & 47.229 & 77.1 & 807 & 757 & 529 & 278 & 0.94 & 0.66 & 0.34 & 0.66 \\
\hline 04045500 & Tahquamenon River near Paradise & 46.575 & 1960.6 & 828 & 832 & 395 & 432 & 1.00 & 0.48 & 0.52 & 0.73 \\
\hline 04057510 & Sturgeon River near Nahma Junction & 45.943 & 475.4 & 826 & 866 & 348 & 478 & 1.05 & 0.42 & 0.58 & 0.74 \\
\hline 04059500 & Ford River near Hyde & 45.755 & 1156.8 & 776 & 843 & 278 & 499 & 1.09 & 0.36 & 0.64 & 0.68 \\
\hline 04096405 & Sturgeon River at Wolverine & 45.274 & 454.7 & 850 & 906 & 402 & 449 & 1.07 & 0.47 & 0.53 & 0.80 \\
\hline 04105000 & Manistee River near Sherman & 44.436 & 2241.9 & 835 & 912 & 428 & 407 & 1.09 & 0.51 & 0.49 & 0.80 \\
\hline 04105700 & Pere Marquette River at Scottville & 43.945 & 1787.7 & 883 & 963 & 396 & 487 & 1.09 & 0.45 & 0.55 & 0.79 \\
\hline 04108600 & Macatawa River at State Road near Zeeland & 42.779 & 172.9 & 930 & 951 & 406 & 525 & 1.02 & 0.44 & 0.56 & 0.45 \\
\hline 04108800 & Rabbit River near Hopkins & 42.642 & 174.9 & 938 & 934 & 307 & 631 & 1.00 & 0.33 & 0.67 & 0.70 \\
\hline 04117500 & Thornapple River near Hastings & 42.616 & 1063.4 & 886 & 972 & 328 & 558 & 1.10 & 0.37 & 0.63 & 0.71 \\
\hline 04122500 & Augusta Creek Near Augusta & 42.353 & 95.2 & 949 & 1003 & 394 & 555 & 1.06 & 0.42 & 0.58 & 0.78 \\
\hline 04124000 & Battle Creek at Battle Creek & 42.331 & 710 & 888 & 970 & 335 & 552 & 1.09 & 0.38 & 0.62 & 0.72 \\
\hline 04127997 & St. Joseph River at Burlington & 42.103 & 530.7 & 932 & 957 & 319 & 613 & 1.03 & 0.34 & 0.66 & 0.76 \\
\hline 04161580 & Stony Creek near Romeo & 42.801 & 61.7 & 826 & 925 & 237 & 589 & 1.12 & 0.29 & 0.71 & 0.69 \\
\hline 04164000 & Clinton River near Fraser & 42.578 & 1188.3 & 823 & 943 & 340 & 483 & 1.15 & 0.41 & 0.59 & 0.70 \\
\hline 04166100 & River Rouge at Southfield & 42.448 & 225.3 & 815 & 954 & 307 & 509 & 1.17 & 0.38 & 0.62 & 0.61 \\
\hline
\end{tabular}




\subsection{Water Balance Modeling Based on Budyko Hypothesis}

Budyko [3,4] reported that mean annual $\mathrm{ET}_{\mathrm{a}}$ is primarily controlled by available water and energy. Budyko Hypothesis is a model that represents $\mathrm{ET}_{\mathrm{a}} / \mathrm{P}$ ratio as a function of climatic aridity index. It can be expressed as:

$$
\frac{\mathrm{ET}_{\mathrm{a}}}{\mathrm{P}}=\mathrm{F}\left(\frac{\mathrm{ET}_{\mathrm{p}}}{\mathrm{P}}\right)
$$

where $\mathrm{ET}_{\mathrm{a}} / \mathrm{P}$ is the $\mathrm{ET}_{\mathrm{a}}$ ratio; $\mathrm{ET}_{\mathrm{p}} / \mathrm{P}$ is the climate aridity index; $\mathrm{F}$ is an empirical function.

The relationship presented in Equation (2) assumes that average annual $\mathrm{P}$ and $\mathrm{ET}_{\mathrm{p}}$ are the dominant factors controlling mean annual $\mathrm{ET}_{\mathrm{a}}$. Budyko's Equation can be represented as [4]:

$$
\frac{E T_{a}}{P}=\left\{\frac{E T_{P}}{P} \tanh \left(\frac{P}{E T_{P}}\right)\left[1-\cosh \left(\frac{E T_{P}}{P}\right)+\sinh \left(\frac{E T_{P}}{P}\right)\right]\right\}^{0.5}
$$

To incorporate the effects of factors such as vegetation, soil water storage, and rainfall seasonality, among others, on water balance, Budyko-type equations with adjustable parameters have been developed for various applications [5,12-14,23]. Fu's Equation contains a parameter $(w, w>1)$ that represents the combined effects of climatic conditions (e.g., rainfall seasonality) and catchment characteristics (e.g., vegetation cover, soil properties and catchment topography) on the water balance [15,35]. Fu's Equation can be expressed as:

$$
\frac{E T_{a}}{P}=1+\frac{E T_{P}}{P}-\left[1+\left(\frac{E T_{p}}{P}\right)^{w}\right]^{\frac{1}{w}}
$$

In this study, $\mathrm{ET}_{\mathrm{a}}$ was derived from water balance equation (i.e., $\mathrm{ET}_{\mathrm{a}}=\mathrm{P}-\mathrm{Q}$ ) and $\mathrm{w}$ was fitted using SOLVER in Microsoft Excel 2010. The average fitted $\mathrm{w}(\mathrm{w}=1.95)$ was utilized for calculating mean annual $\mathrm{Q}$ using the following equation:

$$
\mathrm{Q}=\mathrm{P}\left[1+\left(\frac{E T_{\mathrm{p}}}{\mathrm{P}}\right)^{\mathrm{w}}\right]^{\frac{1}{\mathrm{w}}}-\mathrm{ET}_{\mathrm{p}}
$$

RMSE (Root Mean Square Error) was used to evaluate the performance of Fu's Equation (w = 1.95) in the estimation of mean annual streamflow of 17 watersheds in Michigan. The corresponding equation was expressed as:

$$
\operatorname{RSME}=\sqrt{\frac{\sum_{\mathrm{i}=1}^{\mathrm{n}}\left(\mathrm{Q}_{\text {obs,i }}-\mathrm{Q}_{\text {pred, }}\right)^{2}}{\mathrm{n}}}
$$

where Qobs,i is the observed mean annual streamflow (mm/year); Qpred,i is the predicted mean annual streamflow ( $\mathrm{mm} /$ year); $\mathrm{n}$ is the total number of the study watersheds $(\mathrm{n}=17)$. 


\subsection{Climate Sensitivity of Streamflow Based on the Budyko Hypothesis}

The sensitivity of mean annual $\mathrm{Q}$ to variations in mean annual $\mathrm{P}$ and $\mathrm{ET}_{\mathrm{p}}$ in individual watersheds was evaluated using an analytical framework proposed by Roderick and Farquhar [8]. The framework described that changes in $\mathrm{Q}$ in a watershed is a function of changes in climate variables (i.e., $\mathrm{P}$ and $\mathrm{ET}_{\mathrm{p}}$ ) and watershed properties (w) (i.e., changes to climate variability, topography, soil type and vegetation, etc.). Following Roderick and Farquhar [8] and neglecting variation in watershed properties, the influence of mean annual $\mathrm{P}$ and $\mathrm{ET}_{\mathrm{p}}$ on variation in mean annual $\mathrm{Q}$ can be expressed as $[8,36]$ :

$$
\mathrm{dQ}=\frac{\partial \mathrm{Q}}{\partial \mathrm{P}} \mathrm{dP}+\frac{\partial \mathrm{Q}}{\partial \mathrm{ET}_{\mathrm{p}}} \mathrm{dET}_{\mathrm{p}}
$$

where partial derivatives (i.e., $\partial \mathrm{Q} / \partial \mathrm{P}$ and $\partial \mathrm{Q} / \partial \mathrm{ET}$ ) represent $\mathrm{Q}$ sensitivity to a 1-unit variation in mean annual $\mathrm{P}$ and $\mathrm{ET}_{\mathrm{p}}$. Larger $\partial \mathrm{Q} / \partial \mathrm{P}$ and $\partial \mathrm{Q} / \partial \mathrm{ET}$ v values represent greater influence of variation in mean annual $\mathrm{P}$ and $\mathrm{ET}_{\mathrm{p}}$ on $\mathrm{Q}$.

In the Equation (7), $\partial \mathrm{Q} / \partial \mathrm{P}$ and $\partial \mathrm{Q} / \partial \mathrm{ET}_{\mathrm{p}}$ were computed from Fu's Equation (Equation (5)). The mathematical expressions for computing $\partial \mathrm{Q} / \partial \mathrm{P}$ and $\partial \mathrm{Q} / \partial \mathrm{ET}$ P can be expressed as [8]:

$$
\begin{gathered}
\frac{\partial \mathrm{Q}}{\partial \mathrm{P}}=\left[1+\left(\frac{\mathrm{ET}}{\mathrm{P}}\right)^{\mathrm{w}}\right]^{\frac{1}{\mathrm{w}}}-\left(\frac{\mathrm{ET}}{\mathrm{p}}\right)^{\mathrm{w}}\left[1+\left(\frac{\mathrm{ET}}{\mathrm{P}}\right)^{\mathrm{w}}\right]^{\frac{1}{\mathrm{w}}-1} \\
\frac{\partial \mathrm{Q}}{\partial \mathrm{ET}_{\mathrm{p}}}=\left(\frac{\mathrm{ET}_{\mathrm{p}}}{\mathrm{P}}\right)^{\mathrm{w}-1}\left[1+\left(\frac{\mathrm{ET}_{\mathrm{p}}}{\mathrm{P}}\right)^{\mathrm{w}}\right]^{\frac{1}{\mathrm{w}}-1}-1
\end{gathered}
$$

Rearranging Equation (7) by dividing by mean annual Q, the percent change in mean annual Q response to percent change in mean annual $\mathrm{P}$ and ETP was computed as [8]:

$$
\frac{\mathrm{dQ}}{\mathrm{Q}}=\left(\frac{\mathrm{P}}{\mathrm{Q}} \frac{\partial \mathrm{Q}}{\partial \mathrm{P}}\right) \frac{\mathrm{dP}}{\mathrm{P}}+\left(\frac{\mathrm{ET}_{\mathrm{p}}}{\mathrm{Q}} \frac{\partial \mathrm{Q}}{\partial E T_{\mathrm{p}}}\right) \frac{\mathrm{dET}_{\mathrm{p}}}{\mathrm{ET}_{\mathrm{p}}}
$$

where the functional expressions in brackets are the sensitivity coefficients of Q responses to $\mathrm{P}$ and ETP changes, respectively.

Sensitivity coefficients in Equation (10) refer to the proportional change in Q relative to a $1 \%$ change in $\mathrm{P}$ and ETP. For example, sensitivity coefficients of $\mathrm{Q}$ responses to $\mathrm{P}$ and ETP changes in Equation (10) were 0.5 and -0.5 , respectively, indicating a $10 \%$ increase in P increased Q by $5 \%$ while a $10 \%$ increase in $\mathrm{ET}_{\mathrm{P}}$ decreased Q by $5 \%$.

\section{Results and Discussion}

\subsection{Mean Annual Water Balance in the Study Watersheds}

The spatial variation in $\mathrm{ET}_{\mathrm{p}} / \mathrm{P}$ in the study watersheds was ranged from 0.94 to 1.17 (Table 1). This indicates that all the study watersheds are in a sub-humid climatic zone according to a study by Ponce et al. [37], in which the authors reported that climatic spectrum could be divided into eight types depending on $\mathrm{ET}_{\mathrm{p}} / \mathrm{P}$ ranges. $\mathrm{Xu}$ et al. [38] also reported similar $\mathrm{ET}_{\mathrm{p}} / \mathrm{P}$ ratios, which vary from 0.87 to 1.33 in 55 watersheds across the Midwest United States. Mean annual ETa/P ratio and runoff 
coefficient $(\mathrm{Q} / \mathrm{P})$ in the study watersheds varied from 0.34 to 0.71 and from 0.29 to 0.66 , respectively (Table 1). Low ETa/P ratio under similar $\mathrm{P}$ was likely attributed to snowiness as $\mathrm{Q}$ in the Trap Rock River watershed mainly originated from snow fall and spring snowmelt [24]. Berghuijs et al. [39] also reported that snowy catchments have a high runoff ratio in context of the Budyko hypothesis. On average, $40 \%$ of long-term $\mathrm{P}$ in the study watersheds was converted into surface runoff. Mean annual $\mathrm{Q} / \mathrm{P}$ ratios were large for watersheds with high $\mathrm{BFI}$ values, while the corresponding $\mathrm{ET}_{\mathrm{a}} / \mathrm{P}$ ratios were low. As shown in Figure 1, the relationship between mean annual $\mathrm{ET}_{\mathrm{a}} / \mathrm{P}$ and $\mathrm{ET}_{\mathrm{p}} / \mathrm{P}$ ratios in the study watersheds satisfied Fu's curve with $\mathrm{w}=1.95$. Results indicated that estimated mean annual Q using Fu's Equation (Equation (5)) agreed relatively well with observed mean annual Q with RMSE value of $64.1 \mathrm{~mm} /$ year (Figure 2).

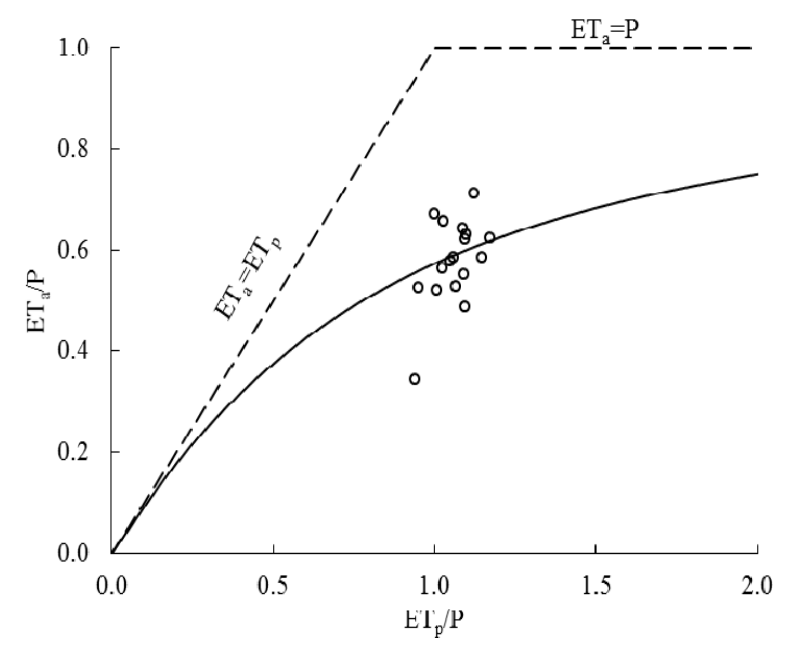

Figure 1. Comparison of observed and calculated (using Fu's Equation) $\mathrm{ET}_{\mathrm{a}} / \mathrm{P}$ in the study watersheds.

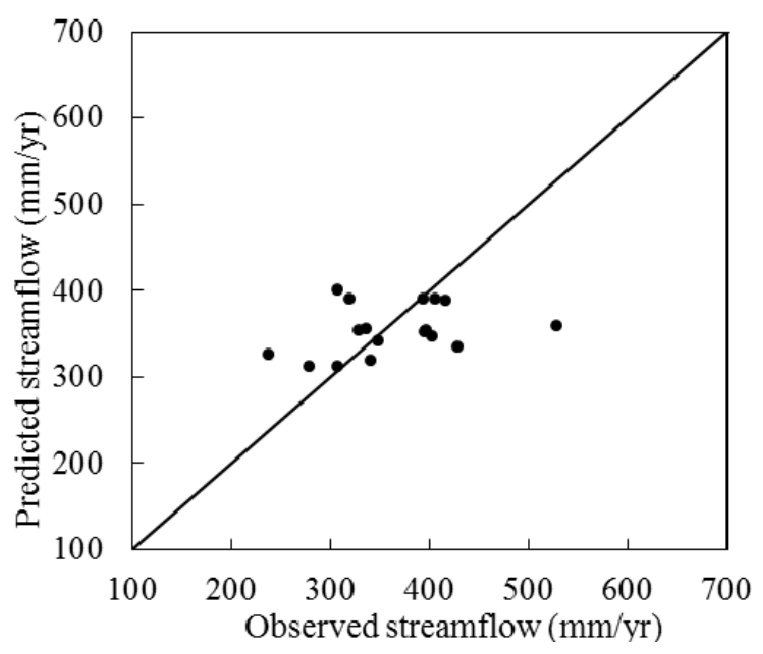

Figure 2. Predicted vs. observed mean annual streamflow in the study watersheds.

\subsection{Impact of Climatic Controls on Mean Annual Water Balance}

Q sensitivity analysis indicated that mean annual Q increased from $12.6 \%$ in the Trap Rock River watershed to $20.6 \%$ in the Stony Creek watershed with an average value of $16.7 \%$ when mean annual $\mathrm{P}$ increased by $10 \%$ (Table 2). A $10 \%$ increase in $\mathrm{ET}_{\mathrm{p}}$ decreased $\mathrm{Q}$ from $2.7 \%$ in the Trap Rock River 
watershed to $10.9 \%$ in the Stony Creek watershed with an average value of $6.9 \%$ (Table 2). Results also showed that streamflow sensitivity to changes in $\mathrm{P}$ and $\mathrm{ET}_{\mathrm{p}}$ had a decreasing trend from north to south. Overall, mean annual $\mathrm{Q}$ was sensitive to variations in mean annual $\mathrm{P}$ and less sensitive to variations in mean annual $\mathrm{ET}_{\mathrm{p}}$ for the period of 1967-2011 in all 17 watersheds. Similar results were found in a study conducted by Donohue et al. [40], in which the authors reported that Q increased by $7 \mathrm{~mm} /$ year with a $10 \mathrm{~mm} /$ year increase in $\mathrm{P}$, and decreased by $4 \mathrm{~mm} /$ year for the same increase in $\mathrm{ET}_{\mathrm{p}}$ in Australia for the period of 1981-2006. Roderick and Farquhar [8] applied this method in the semi-arid Murray Darling Basin in Australia and indicated that a 10\% change in long-term average $\mathrm{P}$ yielded approximately $26 \%$ change in average Q. Herein, streamflow deviation ratio (SDR) (i.e., the ratio of the standard deviation of annual Q to that of annual P) proposed by Koster and Suarez [41] was used in this study to demonstrate the sensitivity of the variability in inter-annual $Q$ to the variation in inter-annual P. Results indicated that SDR ranged from 0.35 in the Manistee River watershed to 1.05 in the Macatawa River watershed, suggesting that the majority of inter-annual $\mathrm{P}$ variability became inter-annual Q variability for the Macatawa River watershed, while inter-annual Q variability was largely less sensitive to variability in inter-annual $\mathrm{P}$ for the Manistee River watershed. SDR was low for watersheds with high BFI values, indicating that inter-annual Q variability was largely less sensitive to variability in inter-annual $P$ for watersheds with high BFI values. It seemed that different contributions of baseflow to streamflow modified the impact of climate controls on water balance in the baseflow-dominated watersheds. That is to say, mean annual Q was less sensitive to climate change with the increase of BFI. Zeng and Cai [42] attributed ET variance to both the mean and variance of climatic variables by extending the framework of Koster and Suarez [41]. Results showed that catchment storage change played a significant role to buffer the inter- and intra-annual variance of ET in the Murray-Darling Basin.

Table 2. Sensitivity of mean annual $\mathrm{Q}$ to variations in mean annual $\mathrm{P}$ and $\mathrm{ET}_{\mathrm{p}}$ in the study watersheds in Michigan.

\begin{tabular}{ccccc}
\hline Gaging Station ID & $\partial \boldsymbol{Q} / \partial \boldsymbol{P}$ & $\partial \boldsymbol{Q} / \partial \boldsymbol{E} \boldsymbol{T}_{\boldsymbol{p}}$ & $(\boldsymbol{P} / \boldsymbol{Q}) \times(\partial \boldsymbol{Q} / \partial \boldsymbol{P})$ & $\left(\boldsymbol{E} \boldsymbol{T}_{p} / \boldsymbol{Q}\right) \times\left(\partial \boldsymbol{Q} / \partial \boldsymbol{E} \boldsymbol{T}_{\boldsymbol{p}}\right)$ \\
\hline 04040500 & 0.74 & -0.29 & 1.57 & -0.58 \\
04043050 & 0.83 & -0.19 & 1.26 & -0.27 \\
04045500 & 0.73 & -0.26 & 1.53 & -0.54 \\
04057510 & 0.69 & -0.26 & 1.64 & -0.66 \\
04059500 & 0.65 & -0.27 & 1.80 & -0.83 \\
04096405 & 0.66 & -0.31 & 1.92 & -0.93 \\
04105000 & 0.66 & -0.26 & 1.75 & -0.76 \\
04105700 & 0.69 & -0.26 & 1.66 & -0.67 \\
04108600 & 0.65 & -0.33 & 2.00 & -1.02 \\
04108800 & 0.71 & -0.27 & 1.62 & -0.63 \\
04117500 & 0.66 & -0.26 & 1.77 & -0.78 \\
04122500 & 0.70 & -0.24 & 1.56 & -0.58 \\
04124000 & 0.74 & -0.21 & 1.44 & -0.45 \\
04127997 & 0.72 & -0.24 & 1.52 & -0.54 \\
04161580 & 0.59 & -0.28 & 2.06 & -1.09 \\
04164000 & 0.67 & -0.23 & 1.62 & -0.64 \\
04166100 & 0.64 & -0.23 & 1.70 & -0.72 \\
\hline
\end{tabular}




\section{Discussions}

\subsection{Compared with Other Similar Studies}

All 17 study watersheds were located in a sub-humid climatic zone and thus climatic conditions of these watersheds were similar. However, $\mathrm{ET}_{\mathrm{a}} / \mathrm{P}$ ratios varied across the study watersheds. Previous studies suggested that differences in $\mathrm{ET}_{\mathrm{a}} / \mathrm{P}$ ratios under the same climatic aridity index were explained by land cover and/or soil texture $[13,14,23]$. Watersheds, such as Stony Creek watershed and Clinton River watershed had similar climate conditions $\left(\mathrm{P}\right.$ and $\left.\mathrm{ET}_{\mathrm{p}} / \mathrm{P}\right)$, with $\mathrm{ET}_{\mathrm{a}} / \mathrm{P}$ ratios of 0.71 and 0.59 , respectively (Table 1). This may be due to the different percentages of soil types and land cover $[43,44]$, with hydrologic soil group B comprising $73 \%$ and $57 \%$ of Stony Creek watershed and Clinton River watershed, respectively. Stony Creek watershed was mainly covered by forest (37\%) while developed land cover constituted $65 \%$ of the Clinton River watershed. Overall, the varying $\mathrm{ET}_{\mathrm{a}} / \mathrm{P}$ ratios in the study watersheds could be the result of combinatory effects of land cover and soil properties. The average $\mathrm{Q} / \mathrm{P}$ value of 0.42 during the 1967-2011 study period suggested that about 40\% of long-term $\mathrm{P}$ in the study watersheds was converted into surface runoff. Similar results were found by Tekleab et al. [17], where Q/P ratios varied from 0.21 to 0.70 for 20 watersheds in the Upper Blue Nile basin. By contrast, $\mathrm{Q} / \mathrm{P}$ ratios of 34 subbasins in the Nebraska Sand Hills reported by Wang et al. [23] were very low, ranging between 0.01 and 0.18 , which can be explained by the high infiltration capacity of sandy soils in the Nebraska Sand Hills.

On average, $70 \%$ streamflow was contributed by baseflow in the studied watersheds [24]. As shown in Figure 3, the correlation coefficient between $\mathrm{Q} / \mathrm{P}$ and BFI in the remaining 15 watersheds (Trap Rock River and Macatawa River watersheds were excluded) approaches to 0.5. It is suggested that $\mathrm{Q} / \mathrm{P}$ ratios increased with the increase of BFIs. Similar results were reported by [23], which indicated that higher BFI values and $\mathrm{Q} / \mathrm{P}$ ratio could be explained by higher groundwater recharge. Watersheds with similar BFI values would have similar ETa/P ratios (e.g., Thornapple River and Battle Creek) (Table 1). Inversely, if BFI values were different, $\mathrm{ET}_{\mathrm{a}} / \mathrm{P}$ ratios would be different. Although average annual water balance was principally controlled by available water and energy (i.e., $\mathrm{P}$ and $\mathrm{ET}_{\mathrm{p}}$ ), factors such as rainfall seasonality, root zone storage capacity and snowiness have also been shown to be major controls on long-term water balance behavior [13,45]. Since Q/P ratio for the Trap Rock River and Macatawa River watersheds seemed unusual compared to the other study watersheds; they were not used for the analysis. As mentioned in Section 3.1., large Q in the Trap Rock River watershed could be the influence of heavy snow and large amounts of spring snowmelt. Low BFI values in the Macatawa River watershed could be explained by large proportions of agricultural and urban land uses as well as soil texture (dominated by hydrologic soil group C) that would reduce the rate of water transmission of the underlying aquifer and groundwater discharge into the streams [24]. Similar findings were reported in previous studies [8,23]. Wang et al. [23] indicated that soil texture altered the influence of climate on regional water balances to large extent and water storage should be included in the Budyko Hypothesis for baseflow-dominated watersheds. 


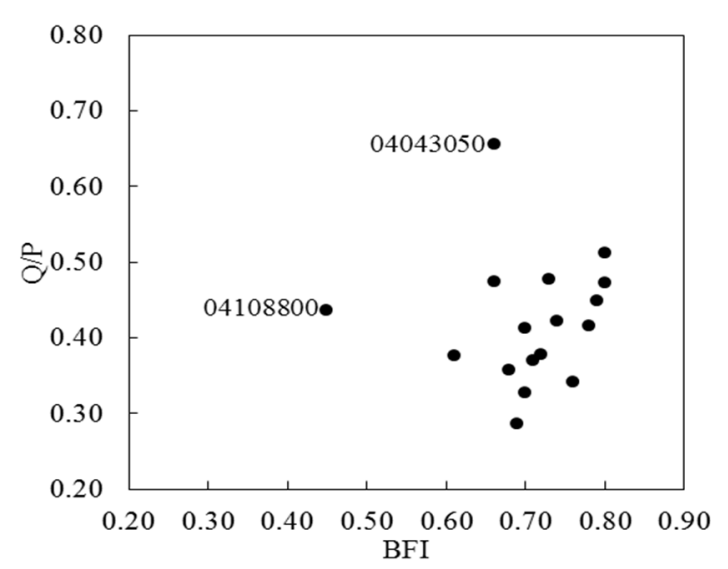

Figure 3. Relationship between runoff coefficient $(\mathrm{Q} / \mathrm{P})$ and baseflow index (BFI).

\subsection{Limitations}

$\mathrm{ET}_{\mathrm{p}}$ is an important variable for estimating $\mathrm{ET}_{\mathrm{a}}$ and climate aridity index in hydrological modeling. Limited to the data availability, the Hargreaves method [30] was selected to calculate ET in this study. Since the Hargreaves equation was originally calibrated using data from California, the transferability of this equation to other regions is quite limited. The reliability of $\mathrm{ET}_{\mathrm{p}}$ estimates can be improved by adding more relevant input variables [46,47]. Thus, the impact of $\mathrm{ET}_{\mathrm{p}}$ calculated by Hargreaves method on mean annual water balance at watershed scales need to be further explored. Although Fu's Equation was employed to estimate the role of climate changes on changing water balance conditions in this study, comparison of other empirical equations based on Budyko Hypothesis is necessary to be conducted in the future studies. In addition, watershed characteristics such as vegetation cover, soil properties and watershed topography were integrated in parameter $\mathrm{w}$ in Fu's equation [15]; however, values of $\mathrm{w}$ in individual watersheds in this study were simply fitted between the observed $\mathrm{ET}_{\mathrm{a}} / \mathrm{P}_{\mathrm{P}}$ and $\mathrm{ET}_{\mathrm{p}} / \mathrm{P}$ ratios. This may result in limitations in using $\mathrm{Fu}$ 's Equation for mean annual water balance estimation. Some studies have focused on the development of w estimation to improve the predictive ability of Fu's Equation [45,48-50]. In addition, watershed boundaries were not considered in this study. This may result in water exchange within the adjacent watersheds, thereby limiting the accuracy of Fu's Equation in estimating mean annual water balance in the study watersheds.

\section{Conclusions}

Mean annual water balances in 17 watersheds across Michigan were estimated using Fu's equation, which is based on the Budyko Hypothesis. The role of climate controls (e.g., $\mathrm{P}$ and $\mathrm{ET}_{\mathrm{p}}$ ) on mean annual water balance was investigated with Fu's Equation. Results indicated that estimated mean annual Q using Fu's Equation agreed relatively well with observed mean annual Q with RMSE value of $64.1 \mathrm{~mm} / \mathrm{year}$. On average, $40 \%$ of long-term $\mathrm{P}$ in the study watersheds was converted into surface runoff. Mean annual Q/P ratios were large for watersheds with high BFI values, while the corresponding $\mathrm{ET}_{\mathrm{a}} / \mathrm{P}$ ratios were low, suggesting that $\mathrm{Q}$ was closely related to regional groundwater discharge. Climate sensitivity of mean annual $\mathrm{Q}$ showed that a $10 \%$ increase in mean annual $\mathrm{P}$ increased mean annual $\mathrm{Q}$ by $16.7 \%$, while a $10 \%$ increase in mean annual $\mathrm{ET}_{\mathrm{p}}$ decreased $\mathrm{Q}$ by $6.9 \%$ on average. This suggested that mean annual $\mathrm{Q}$ was sensitive to changes in mean annual $\mathrm{P}$ and less 
sensitive to changes in mean annual $\mathrm{ET}_{\mathrm{p}}$ in all 17 watersheds. It seemed that different contributions of baseflow to streamflow modified the impact of climate controls on annual water balance in the baseflow-dominated watersheds.

\section{Acknowledgments}

This study was supported by the China Scholarship Council (CSC) and the Department of Agricultural and Biological Engineering in Purdue University. The authors would like to thank two anonymous reviewers for their constructive comments and suggestions to improve the manuscript.

\section{Author Contributions}

Yinqin Zhang completed all computational analyses and wrote the paper; Bernard Engel and Laurent Ahiablame reviewed the paper and contributed to the interpretation and summarization of the results and discussion in the article; Junmin Liu directed this research.

\section{Conflicts of Interest}

The authors declare no conflict of interest.

\section{References}

1. Schreiber, P. Ueber die beziehungen zwischen dem niederschlag und der wasseruhrung der flusse in Mitteleuropa. Meteorol. Z. 1904, 21, 441-452.

2. Ol'dekop, E.M. On evaporation from the surface of river basins. Trans. Meteorol. Observ. 1911, 4, 200.

3. Budyko, M.I. The Heat Balance of the Earth's Surface; US Department of Commerce: Washington, DC, USA, 1958.

4. Budyko, M.I. Climate and Life; Academic Press: San Diego, CA, USA, 1974; p. 508.

5. Choudhury, B.J. Evaluation of an empirical equation for annual evaporation using field observations and results from a biophysical model. J. Hydrol. 1999, 216, 99-110.

6. Sankarasubramanian, A.; Vogel, R.M. Annual hydroclimatology of the United States. Water. Resour. Res. 2002, 38, doi:10.1029/2001WR000619.

7. Donohue, R.J.; Roderick, M.L.; McVicar, T.R. On the importance of including vegetation dynamics in Budyko's hydrological model. Hydrol. Earth. Syst. Sci. 2007, 11, 983-995.

8. Roderick, M.L.; Farquhar, G.D. A simple framework for relating variations in runoff to variations in climatic conditions and catchment properties. Water. Resour. Res. 2011, 47, doi:10.1029/2010WR009826.

9. Xiong, L.; Guo, S. Appraisal of Budyko formula in calculating long-term water balance in humid watersheds of southern China. Hydrol. Process. 2012, 26, 1370-1378.

10. Turc, L. The water balance of soils. Relation between precipitation evaporation and flow. Ann. Agron. 1954, 5, 491-569.

11. Pike, J.G. The estimation of annual runoff from meteorological data in a tropical climate. J. Hydrol. 1964, 2, 116-123. 
12. Fu, B. On the calculation of the evaporation from land surface. Sci. Atmos. Sin. 1981, 5, 23-31. (in Chinese)

13. Milly, P.C.D. Climate, soil water storage, and the average annual water balance. Water. Resour. Res. 1994, 30, 2143-2156.

14. Zhang, L.; Dawes, W.R.; Walker, G.R. Response of mean annual evapotranspiration to vegetation changes at catchment scale. Water. Resour. Res. 2001, 37, 701-708.

15. Zhang, L.; Hickel, K.; Dawes, W.R. A rational function approach for estimating mean annual Evapotranspiration. Water. Resour. Res. 2004, 40, doi:10.1029/2003WR002710.

16. Potter, N.J.; Zhang, L. Interannual variability of catchment water balance in Australia. J. Hydrol. 2009, 369, 120-129.

17. Tekleab, S.; Uhlenbrook, S.; Mohamed, Y.; Savenije, H.H.G.; Temesgen, M.; Wenninger, J. Water balance modeling of Upper Blue Nile catchments using a top-down approach. Hydrol. Earth. Syst. Sci. 2011, 15, 2179-2193.

18. Zhang, L.; Potter, N.; Hickel, K.; Zhang, Y.; Shao, Q. Water balance modeling over variable time scales based on the Budyko framework-Model development and testing. J. Hydrol. 2008, 360, 117-131.

19. Wang, H.; Yu, X. Sensitivity analysis of climate on streamflow in north China. Theor. Appl. Climatol. 2015, 119, 391-399.

20. Liu, X.; Liu, W.; Xia, J. Comparison of the streamflow sensitivity to aridity index between the Danjiangkou Reservoir basin and Miyun Reservoir basin, China. Theor. Appl. Climatol. 2013, 111, 683-691.

21. Wang, D.; Hejazi M. Quantifying the relative contribution of the climate and direct human impacts on mean annual streamflow in the contiguous United States. Water. Resour. Res. 2011, 47, W00J12.

22. Teng, J.; Chiew, F.H.S.; Vaze, J. Estimation of climate change impact on mean annual runoff across continental Australia using Budyko and $\mathrm{Fu}$ equations and hydrological models. J. Hydrometeorol. 2012, 13, 1094-1106.

23. Wang, T.; Istanbulluoglu, J.L.; Scott, D. On the role of groundwater and soil texture in the regional water balance: An investigation of the Nebraska Sand Hills, USA. Water. Resour. Res. 2009, 45, doi:10.1029/2009WR007733.

24. Zhang, Y.; Ahiablame, L.; Engel, B.; Liu, J. Regression modeling of baseflow and baseflow index for Michigan USA. Water 2013, 5, 1797-1815.

25. Daly, C.; Neilson, R.P.; Philips, D.L. A statistical-topographic model for mapping climatological precipitation over mountainous terrain. J. Appl. Meteorol. 1994, 33, 140-158.

26. ArcGIS 10. Environmental Systems Resource Institute, Inc: Redlands, CA, USA, 2010.

27. USGS Current Water Data for the Nation. Available online: http://waterdata.usgs.gov/usa/nwis/rt (accessed on 10 November 2012).

28. Eckhardt, K. How to construct recursive digital filters for baseflow separation. Hydrol. Process. 2005, 19, 507-515.

29. Lim, K.J.; Engel, B.A.; Tang, Z.; Chou, J.; Kim, K.S.; Muthukrishnan, S.; Tripathy, D. Automated web GIS-based hydrograph analysis tool, WHAT. J. Am. Water. Resour. Assoc. 2005, 41, $1407-1416$. 
30. Hargreaves, G.H; Samani, Z.A. Reference crop evapotranspiration from temperature. Appl. Eng. Agric. 1985, 1, 96-99.

31. Sankarasubramanian, A.; Vogel, R.M.; Limbrunner, J.F. Climate elasticity of streamflow in the United States. Water. Resour. Res. 2001, 37, 1771-1781.

32. Hargreaves, G.H.; Allen, R.G. History and evaluation of Hargreaves evapotranspiration equation. J. Irrig. Drain. Eng. 2003, 129, 53-63.

33. Bachour, R.; Walker, W.R.; Torres-Rua, A.F.; McKee, M. Assessment of reference evapotranspiration by the Hargreaves method in the Bekaa Valley, Lebanon. J. Irrig. Drain. Eng. 2013, 139, 933-938.

34. Calculation of extraterrestrial solar radiation (to horizontal surface at top of atmosphere). Available online: http://www.engr.scu.edu/ emaurer/tools/calc_solar_cgi.pl (accessed on 20 April 2014).

35. Yang, D.; Sun, F.; Liu, Z.; Cong, Z.; Lei, Z. Interpreting the complementary relationship in non-humid environments based on the Budyko and Penman hypotheses. Geophys. Res. Lett. 2006, 33, doi:10.1029/2006GL027657.

36. Wang, D.; Alimohammadi, N. Responses of annual runoff, evaporation, and storage change to climate variability at the watershed scale. Water. Resour. Res. 2012, 48, doi:10.1029/2011WR011444.

37. Ponce, V.M.; Pandey, R.P.; Ercan, S. Characterization of drought across the climate spectrum. J. Hydrol. Eng. 2000, 5, 222-224.

38. Xu, X.; Scanlon, B.R.; Schilling, K.; Sun, A. Relative importance of climate and land surface changes on hydrologic changes in the US Midwest since the 1930s: Implications for biofuel production. J. Hydrol. 2013, 497, 110-120.

39. Berghuijs, W.R.; Woods, R.A.; Hrachowitz, M. A precipitation shift from snow towards rain leads to a decrease in streamflow. Nat. Clim. Chang. 2014, 4, 583-586.

40. Donohue, R.J.; Roderick, M.L.; McVicar, T.R. Assessing the differences in sensitivities of runoff to changes in climatic conditions across a large basin. J. Hydrol. 2011, 406, 234-244.

41. Koster, R.D.; Suarez, M.J. A simple framework for examining the interannual variability of land surface moisture fluxes. J. Clim. 1999, 12, 1911-1917.

42. Zeng, R.; Cai, X. Assessing the temporal variance of evapotranspiration considering climate and catchment storage factors. Adv. Water. Resour. 2015, 79, 51-60.

43. National Land Cover Data (NLCD). Available online: http://seamless.usgs.gov (accessed on 30 November 2012).

44. Soil Survey Geographic Database (SSURGO). Available online: http://soils.usda.gov/survey/ geography (accessed on 8 January 2013).

45. Yang, D;; Sun, F.; Liu, Z.; Cong, Z.; Ni, G.; Lei, Z. Analyzing spatial and temporal variability of annual water-energy balance in nonhumid regions of China using the Budyko hypothesis. Water. Resour. Res. 2007, 43, W04426.

46. Renner, M.; Bernhofer, C. Applying simple water-energy balance frameworks to predict the climate sensitivity of streamflow over the continental United States. Hydrol. Earth. Syst. Sci. 2012, 16, 2531-2546.

47. Donohue, R.J.; McVicar, T.R.; Roderick, M.L. Assessing the ability of potential evaporation formulations to capture the dynamics in evaporative demand within a changing climate. J. Hydrol. 2010, 386, 186-197. 
48. Yang, D.; Shao, W.; Yeh, P.J.F.; Yang, H.; Kanae, S.; Oki, T. Impact of vegetation coverage on regional water balance in the nonhumid regions of China. Water. Resour. Res. 2009, 45, doi:10.1029/2008WR006948.

49. Donohue, R.J.; Roderick, M.L.; McVicar, T.R. Roots, storms and soil pores: Incorporating key ecohydrological processes into Budyko's hydrological model. J. Hydrol. 2012, 436-437, 35-50.

50. Xu, X.; Liu, W.; Scanlon, B.R.; Zhang, L.; Pan, M. Local and global factors controlling water-energy balances within the Budyko framework. Geophys. Res. Lett. 2013, 40, 6123-6129.

(C) 2015 by the authors; licensee MDPI, Basel, Switzerland. This article is an open access article distributed under the terms and conditions of the Creative Commons Attribution license (http://creativecommons.org/licenses/by/4.0/). 